\section{Framing the Framework The Rigorous Responsibilities of Library and Information Science}

\author{
Nathan W. Filbert \\ Nathan Filbert is Assistant Professor, Instruction \\ and Research Services Librarian at Wichita \\ State University, Wichita, Kansas. \\ Correspondence concerning this column should be \\ addressed to Marianne Ryan, Associate University \\ Librarian for User Service Strategies, Northwestern \\ University, 1970 Campus Drive, Evanston, IL 60208; \\ email:marianne-ryan@northwestern.edu.
}

The ACRL Framework for Information Literacy for Higher Education offers library and information science (LIS) professionals a conceptual approach for leading information literacy efforts in a digital environment. But while a good start, Nathan Filbert suggests that it is not enough to validate librarianship's transdisciplinary potential. In this column, Filbert addresses the programmatic and directional efforts necessary for LIS to realize expansive expertise in information resource management, reference, and user services in the evolving, complex, information ecosystem. Drawing on the profession's past and present, he suggests a vision and a philosophy for mediating the infosphere of the future.-Editor

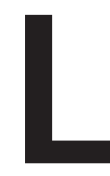

ibrarianship is inherently a transdisciplinary vocation. ${ }^{1}$ Functioning as a nexus of information resources and literacy instruction for diverse communities, disciplines, businesses, and patrons, librarians must possess the know-how of utilizing manifold technologies, vocabularies and discourses, media, and styles to help participants discover, discern, and deploy the best resources for a given need.

Librarianship tends to focus on principles and practices in the fulfilment of its vocation. Problem- and project-based inquiry and resolution processes feature prominently in library-related work and, coupled with objectives of providing access to global information resources, result in an institution and profession expert in adaptation, assimilation, and reconstruction. These admirable objectives have clearly served the profession well, surviving since the beginning of recorded knowledge.

Technological developments across the past century, particularly in relation to communication and information processes, are comprehensively reshaping human reality. All aspects of lived experience-environment, relationships, activities, and knowledge-are metamorphosing and evolving symbiotically as digital/analog fusion is being composed. Paradigms shift accordingly. No field of human inquiry is not grappling with these changes and their rapidity. Our disciplines and discourses, politics, and economies all recognize the necessity of emerging from discrete areas of expertise toward multidisciplinary, interdisciplinary, and, ultimately, transdisciplinary understandings as implied by our networks and connectivities. "'Cyberculture,' 'posthumanism,' 'singularity,' and other similarly fashionable ideas can all be understood as attempts to make sense of our new hyperhistorical predicament ... but the hole is way deeper, the problem much more profound. We need to do some serious philosophical digging." 


\section{MANAGEMENT}

Addressing this "problem" (or opportunity?) within librarianship, the Association of College and Research Libraries (ACRL) carefully reformed and revised the "Information Literacy Competency Standards for Higher Education" filed in January 2000 into a "richer, more complex set of core ideas," a "Framework for Information Literacy for Higher Education."3 Observing the everyware and onlife realities of digital affordances and the proliferation of miscellaneous resources these enable, ${ }^{4}$ combined with rate of change and variety of software interpretations required, the committee recognized that staged skills and instructions were no longer adequate to the task of effective information acquisition and employment in learning and knowledge creation environments. The following suggestions for change were recommended:

- simplifying so the model will be understood by a range of audiences with appropriate language for these audiences

- addressing affective, emotional learning outcomes; extending the cognitive focus of the current standards

- incorporating components from the metaliteracy conception of information literacy

- reconceptualizing the issues of format

- addressing the role of student as creator and as content curator

- aligning the resulting item with the AASL Standards for the twenty-first century Learner ${ }^{5}$

These resulted in a "cluster of interconnected core concepts, with flexible options for implementation within each unique institutional and disciplinary context": 6

- Authority Is Constructed and Contextual

- Information Creation as a Process

- Information Has Value

- Research as Inquiry

- Scholarship as Conversation

- Searching as Strategic Exploration ${ }^{7}$

In theory, this signals a profound modification in librarianship and literacy instruction, shifting from procedural skills and principled practices toward processual engagements and social, contextual, and creative interactions and evaluation. In libraries, however, (i.e., "in practice") this renewed confession of intentions and values exemplifies their age-old commitments as organizations and institutions, represented here by an accommodation of Ranganathan's Five Laws of Library Science (1931):

1. Information resources are for use.

2. Every user his [or her] resource.

3. Every resource its user.

4. Save the time of the user.

5. The library is a growing organism. ${ }^{8}$

Notably, these "rich, complex core ideas" also work to align library and information science as a discipline with the increasingly inter- and multidisciplinary trends in other professional and academic domains. A glance at the "foundational" and "supplementary" readings provided with the ACRL Framework demonstrate the integration of learning theories, psychology, education, sociology, and information processing theories. ${ }^{9}$ Multidisciplinary in the manner of new media studies, information architecture and design, sustainability and ecology, multicultural education and cultural studies programs, ${ }^{10}$ but not yet truly transdisciplinary. ${ }^{11}$ Information professionals are charged with ensuring the preservation, organization, accessibility, usability, and credibility of global information resources; transdisciplinarity must be a requirement.

In keeping with libraries' proclivity for problem-solving and practicable service, a rush toward implementation has ensued-manifesting in Twitter feeds, conferences and webinars, learning tools and objects, and publications. ${ }^{12}$ While laudable and necessary, the leap to practice runs the risk of merely translating extant information literacy standards into a different set of terms. The Framework intends to provide a reconceptualization and reformulation of just what it means to be information literate in our elaborate, technology-infused, and increasingly uni-mediated environment. And this is why "we need to do some serious philosophical digging . . . to gain a better grasp of our age, and hence a better chance to shape it in the best way and deal successfully with its open problems."13

Traditional philosophy is also an inherently transdisciplinary vocation. Being a "friend to wisdom" entails taking account of the compendium of human knowing-its content, methods, processes, and discourses - "to understand how things in the broadest possible sense of the term hang together in the broadest possible sense of the term." ${ }^{.14}$ Working toward this perimeter, philosophy searches patterns, similarities and assumptions, practices, and problems to move into the not-yet-sayable, the "open problems" and potent questions "to reconsider and redesign our conceptual vocabularies and our ways of giving meaning to, and making sense of, the world."15

If we "envision information literacy as the set of integrated abilities encompassing the reflective discovery of information, the understanding of how information is produced and valued, and the use of information in creating new knowledge and participating ethically in communities of learning," ${ }^{\prime 6}$ we are claiming and requiring of ourselves a robust and comprehensive understanding of the fundamental nature of knowledge, reality, and experience of human life in the infosphere. ${ }^{17}$ What are we in this anthropotechnical world $?^{18}$ Who and how are we in relation to it? $?^{19}$ And what are we able to do?

In-formation carries time-honored considerations and content regarding the process of becoming. Literacy refers to our skillful and competent participation in it. Given our complex, interconnected, hybridized, and ever-proliferating human-digital-environmental living-context, librarianship—or, the vocation charged with organizing, ensuring 
access, and fostering discovery and usability toward the collaborative creation of new knowledge-faces an imperative to dig deeply, consider widely, inquire attentively, and apply carefully our methods and processes of managing information objects.

The comprehensive remediation of information resources into the digital precipitates a universal effect on librarianship. Issues of access, organization, storage, retrieval, and reference are continuously transformed by the fluid and mutable interfaces and platforms constituting this medium. The problems faced in these areas

are neither predictable nor simple but unique and complex. Arising from environments characterized by turbulence and uncertainty, complex problems are typically value-laden, open-ended, multi-dimensional, ambiguous, and unstable. Labelled "wicked" and "messy," they resist being tamed, bounded, or managed by classical problem-solving approaches ... the art of being a modern professional is fast becoming the art of managing complexity ... opening up "indeterminate zones of practice" and a "swamp of important problems and nonrigorous inquiry." Furthermore, they are not solved once and forever. They must be continuously managed. ${ }^{20}$

Complex problems/opportunities such as these must be managed collaboratively and creatively, and involve core components of cognitive, structural and processual leadership. ${ }^{21}$ Inherently transdisciplinary, competency with complexity requires "breaking out of past mindsets and opening up to the content of new agendas ... a task described as framing - the construction of a mental model that provides a sense-making device for team members, captures their beliefs and abilities, and motivates them to work productively."22 ACRL's "Framework for Information Literacy for Higher Education" is a tremendous conceptual structuring tool for our discipline, demonstrating clearly that "the library is a growing organism" embedded in and corresponding with our world. But for a visioning frame to be successful it necessitates clarification and resolution for successful integration. ${ }^{23}$

Structural and processual leadership in this regard urges concerted effort toward collaborative and coordinated comprehension and commitment, crossing traditional boundaries of discourse, scholarship, and profession to fashion dynamic and collective understandings and practices that can be context-specific with multiple stakeholder perspectives. ${ }^{24}$ A changing information ecosystem calls for profound systemic reconstruction guided by transdisciplinary research, multiple champions, and communicative liaisons "managing network stability, knowledge mobility and innovation appropriability." ${ }^{25}$ Further critical inquiry into various methods, discourses, content, and activities must be supported to successfully generate proficient pathways of participation and engagement enabling our communities to thrive.
Developing common language and engendering shared assumptions reflecting the variety and specificity of a "world of concepts, theory, learned knowledge, procedures and paradigms, analytic approaches and methods" 26 that construct the infosphere we propose to steward entreats us to earnest and fundamental revisions in addressing the gaps in our theories and practice. In league with information professionals across disciplines and occupations, we must practice what we preach and discover existing knowledge, query the open problems, and construct significant questions and resolutions toward our future.

\section{References}

1. "Transdisciplinary Research is defined as research efforts conducted by investigators from different disciplines working jointly to create new conceptual, theoretical, methodological, and translational innovations that integrate and move beyond discipline-specific approaches to address a common problem." "Harvard Transdisciplinary Research in Energetics and Cancer Center," Harvard T. H. Chan School of Public Health, accessed September 9, 2015, www.hsph.harvard.edu/trec/about-us/defi nitions.

2. Luciano Floridi, The 4th Revolution: How the Infosphere is Reshaping Human Reality (New York: Oxford University Press, 2014), viii-ix, italics added.

3. "Information Literacy Competency Standards for Higher Education," Association of College and Research Libraries (ACRL), accessed September 8, 2015, www.ala.org/acrl/standards/infor mationliteracycompetency; "Framework for Information Literacy for Higher Education," Association of College and Research Libraries (ACRL), accessed September 8, 2015, www.ala.org/ acrl/standards/ilframework.

4. Floridi, The 4th Revolution; Adam Greenfield, Everyware: The Dawning Age of Ubiquitous Computing (Berekley, CA: New Riders, 2006).

5. Framework for Information Literacy for Higher Education, "History of the Framework for Information Literacy for Higher Education," Association of College and Research Libraries (ACRL), accessed August 31, 2015, www.acrl.ala.org/framework/?page_ $\mathrm{id}=41$.

6. Framework for Information Literacy for Higher Education, "About The Framework for Information Literacy for Higher Education," Association of College and Research Libraries (ACRL), accessed August 31, 2015, www.acrl.ala.org/framework/?page_ $\mathrm{id}=74$.

7. "Framework for Information Literacy for Higher Education," Association of College and Research Libraries (ACRL), accessed September 8, 2015, www.ala.org/acrl/standards/ilframework.

8. "Five Laws of Library Science," Wikipedia, The Free Encyclopedia, accessed June 23, 2015, www.en.wikipedia.org/w/index .php?title=Five_laws_of_library_science\&oldid=665716095.

9. "Framework for Information Literacy Appendixes," Association of College and Research Libraries (ACRL), accessed June 23, 2015, www.ala.org/acrl/standards/ilframeworkapps.

10. See for example Elizabeth A. Baker, The New Literacies: Multiple Perspectives on Research and Practice (New York: Guilford, 2010); Nancy L. Chick and Kathleen McKinney, The Scholarship of Teaching and Learning In and Across the Disciplines (Bloomington: Indiana University Press, 2013); Floridi, The 4th Revolution; Jenna Hartel, "Welcome to Library and Information Science," Journal of Education for Library \& Information Science 53, no. 3. (Summer 2012), 165-75; R. David Lankes, The Atlas of New Librarianship (Cambridge, MA: MIT Press, 2011); William Merrin, Media Studies 2.0 (New York: Routledge, 2014); Marvin Oxenham, Higher 


\section{MANAGEMENT}

Education in Liquid Modernity (New York: Routledge, 2013); Troy A. Swanson and Heather Jagman, Not Just Where to Click: Teaching Students how to Think about Information (Chicago: Association of College and Research Libraries, 2015); Christopher Winch, The Philosophy of Human Learning (New York: Routledge, 1998).

11. See Edgar Morin, On Complexity (Creskill, NJ: Hampton, 2008); Edgar Morin, Seven Complex Lessons in Education for the Future (Paris: UNESCO, 2001); Basarab Nicolescu, Transdisciplinarity: Theory and Practice (Creskill, NJ: Hampton, 2008).

12. See for example, Framework for Information Literacy for Higher Education, "About The Framework for Information Literacy for Higher Education,"; Troy A. Swanson and Heather Jagman, Not Just Where to Click: Teaching Students how to Think about Information.

13. Floridi, The 4th Revolution, $\mathrm{x}$.

14. Wilfrid Sellars, Science, Perception and Reality (New York: The Humanities, 1963), 1.

15. See for example Gilles Deleuze and Felix Guattari, What is Philosophy (New York: Columbia University Press, 1994); Floridi, The 4th Revolution; Eugene T. Gendlin, Thinking Beyond Patterns: Body, Language, and Situations (New York: Peter Lang, 1991); Eugene T. Gendlin, A Process Model (Spring Valley, NY: Focusing Institute, 1997); Eugene T. Gendlin and David M. KleinbergLevin, Language Beyond Postmodernism: Saying and Thinking in Gendlin's Philosophy (Evanston, IL: Northwestern University Press, 1997); Martin Heidegger, What is Philosophy (New York: Twayne Publishers, 1958).

16. Framework for Information Literacy for Higher Education, "About The Framework for Information Literacy for Higher Education."

17. See for example Luciano Floridi, The Philosophy of Information (New York: Oxford University Press, 2011); Floridi, The 4th Revolution; Andrew Hinton, Understanding Context: Environment, Language, and Information Architecture (Sevastopol, CA: O'Reilly Media, 2014); Morin, On Complexity; Peter Morville, Intertwingled (Ann Arbor, MI: Semantic Studios, 2014); Winch, The Philosophy of Human Learning.
18. See for example Gilbert Simondon, L'individuation à la lumière des notions de forme et d'information (Paris: Presses Universitaires de France, 1964); Gilbert Simondon, Ninian Mellamphy, and John Hart, On the Mode of Existence of Technical Objects (London, Ontario: University of Western Ontario, 1980); Peter Sloterdijk and Weiland Hoban, You Must Change Your Life (Cambridge, UK: Polity Press, 2013).

19. See for example Giorgio Agamben, The Coming Community (Minneapolis: University of Minnesota Press, 1993); Alain Badiou and Oliver Feltham, Being and Event (London: Bloomsbury Academic, 2013); Gendlin, Thinking Beyond Patterns; Gendlin, A Process Model; Martin Heidegger, Being and Time (New York: Harper, 1962); Tim Ingold, Being Alive: Essays on Movement, Knowledge and Description (New York: Routledge, 2011); Bruno Latour, An Inquiry into Modes of Existence: An Anthropology of the Moderns (Cambridge, MA: Harvard University Press, 2013).

20. Judith Thompson Klein, "Interdisciplinarity and Complexity: An Evolving Relationship," Emergence: Complexity and Organization 6, no. 1-2 (Fall 2004): 4-5.

21. Barbara Gray, "Enhancing Transdisciplinary Research through Collaborative Leadership," American Journal of Preventive Medicine 35, no. 2 S (2008): S125ff.

22. Ibid., S126.

23. Judith Thompson Klein, "Applying Interdisciplinary Models to Design, Planning, and Policy-Making," Knowledge in Society 3, no. 4. (Winter 1990/91): 41.

24. Wade C. Morse, Max Nielsen-Pincus, and Jo Ellen Force, "Bridges and Barriers to Developing and Conducting Interdisciplinary Graduate-Student Team Research," Ecology \& Society 12, no. 2. (December 2007): 3

25. Gray, "Enhancing Transdisciplinary Research through Collaborative Leadership," S128.

26. Klein, "Applying Interdisciplinary Models to Design, Planning, and Policy-making," 38. 